\title{
Difference in S-curve for different types of construction projects
}

\author{
Ehab Soliman and Khaled Alrasheed* \\ Kuwait University, Civil Engineering Department, Safat 17269, Kuwait \\ *Corresponding Author: k.alrasheed@ku.edu.kw \\ Submitted : 11/04/2020 \\ Revised :21/02/2021 \\ Accepted :28/02/2021
}

\begin{abstract}
Project cash flow and contractor S-curve are tools that can be used to measure, control, and anticipate project progress. Few studies are dedicated to evaluating and judging the behavior of the original S-curve. This study aims to evaluate the similarities and changes of construction projects S-curves between different project types. More than 40 S-curves were collected from the state of Kuwait for different types of construction projects. The list of collected curves is divided into six groups based on the type of client, number of buildings, and number of floors. Statistical analysis is used to compare the curves inside each group of projects. Statistical analysis is done using the test of normality, T-paired test, and then Standard Euclidean Distance that were applied to evaluate the similarity and changes between groups. This study revealed that there is a level of similarity of S-curves for high rise buildings, and there is no similarity of S-curves for one or multibuilding projects. The maximum gap between S-curves for one and high rise building is laying in the middle part of project duration, while the maximum gap between Scurves for multibuilding project is laying in $70 \%$ to $80 \%$ of project duration. This study revealed that the variance of S-curve behaviour indicates that there is no common attitude for all types of construction project types. This study can help construction stakeholders anticipate their expected expenses and help in project cash flow management.
\end{abstract}

Keywords: S-curve; Contractor cash out; Comparison; Construction projects.

\section{INTRODUCTION}

One of the most important success factors for the construction project is to finish the project in a specific time and within the predetermined budget. S-curve is the cumulative contractor cash out representing the contractor planned project incurred cost during the project life. This S-curve is a very powerful tool for project control. During the project life, the S-curve is used as a base for time and budget comparison. S-curve is prepared based on the project schedule and the contracted prices for project items. There are many studies focused on the mathematical bases for forming the project S-curve. In this study, we will study the differences between S-curve for different types of construction projects. This study will focus on the projects in the state of Kuwait as case studies.

In many cases, such as in the Authority of Public Housing Affairs in Kuwait, to accept a contractor cash flow, it should achieve a certain percentage of cumulative S-curve in a definite period for the project. These values are 
fixed for all types of construction project types. In this study, the S-curves for many types of projects will be analysed to identify the level of similarity or differences in S-curves between different types of construction projects.

\section{OBJECTIVE}

This study aims to identify the similarities and differences of S-curve between different types of construction projects. The study aims also to investigate the S-curve behaviour for different types of construction projects.

\section{METHODOLOGY}

Figure 1 shows the study methodology. A literature review for studies was conducted to describe the purpose of S-curve and how it can be generated. Collecting some of S-curves for different types of construction projects was conducted in the last ten years in Kuwait. The collected list of S-curves is divided into six types of projects based on the type of client and the number of buildings and floors. To unite the process of comparison, the collected S-curves are converted to identify the scheduled value of work for every $10 \%$ of project times. Then, we compare the S-curve for each group of project type. The average of S-curve for each group is calculated and statistically analyzed. To compare the means of average S-curves for each group, the test normality and T-paired test are applied. Standard Euclidean distance is used to test the similarity of the resulted S-curves from different types of construction projects.

\section{BACKGROUND}

Money is the most important resource in the construction activity, and control project financial is an important issue for all project stakeholders. Money has the great rule to project day to day execution (Dhamodaran, Divakar 2019). Cash flow management is the main role of project financial control. The cash flow management is considered the main indicator of a business's financial health, implying that proper cash flow management is crucial to the construction business survival (Shash and Qarra, 2018). Estimating project budgeting and monitoring the budget by ensuring effective cost control system to keep continuous control on project financial are a major role of all project management objectives (Banki and Esmaeili 2009). Halpin and Senior (2009) indicated that forecasting cash behavior over a project's duration is a crucial key for controlling project cash effectively. Project cash flow is the difference between cash spent and cash received during a specific period (Tarek \& Yaqiong, 2014). Project cash flow analysis is necessary to eliminate or minimize the possibility of financial failure (Kenley, 2003).

Ikediashi and Okolie (2020) surveyed the risk elements that affect the contractor's cash flow through a survey in Nigeria. The study indicated that the 5 top-rated risk factors affecting contractor's cash flow were delay in payment by client, delay in delivery of materials, contractor's lack of resources, exchange rate, and inflation.

The cash flow consists of two parts: the cash out, which indicates the contractor cumulative costs, versus the cash in, which represents the periodic payments that the contractor can receive from the owner. It is assumed that the profile of the cumulative contractor cost versus elapsed time on projects takes the shape of an S-curve (Mavrotas et al. 2005). The cost flow curve can be simulated accurately based on anticipated monthly cost values. The cost values are used to fit the S-curve, a process that can be used to update all the monthly cost values for a project contract (Hwee and Tiong, 2002). Normally, the S-curve starts flat and then accelerates after that due to work progress. The reason is that projects start slowly when the resources necessarily need to set up, and then projects start to accelerate once all resources have been acquired (Kaka, 1999). 
S-curves have become a necessary tool for project planning and control and progress evaluation during the execution phase. S-curves can be used for several purposes, as a target against which the actual progress of the project can be evaluated at any point in time to monitor whether the project is on schedule (Cheng et al. 2011). The S-curve is developed based on early and late progress activities in two envelope curves. The upper curve corresponds to the curve of project activities earliest times, while the lower curve corresponds to the curve of the latest times. The S-curve envelope is used to measure the efficiency of project progress. If the actual project progress is laying within between the upper and lower curves for S-curve envelope, it means that the project has a good chance to finish within the predefined time boundaries; otherwise, it might be ahead or behind the project schedule (Cristóbal 2017). It is noted that S-curves provide a simple and handy tool with which project managers can control their projects. S-curve results during project duration can be used to forecast the likely duration of the project, and to manage cash flow, current performance status, future necessary cost/duration, etc., for running projects (Barraza et al. 2000).

The quality of the prepared S-curve makes contractors more prepared to deal with project real encounters. Nonrealistic cash flow forecasting is the main cause of financial failure for contractors (Navon R, 1996). To enhance usage of S-curve as a tool for project performance judgement, it is recommended to integrate it with other project management approaches, such as milestone planning (Murmis, 1997).

In this study, S-curves for different types of construction projects are gathered from the state of Kuwait. Kuwait is one of the Arabic Gulf area countries. Kuwait GDP is about 137.9 Billion Kuwaiti Dinar (CBK, 2018) (Kuwait Dinar is about 3.3 \$). The construction contribution to GDP is about 7\% (Kuwait-CSB 2019).

The Kuwait construction industry is characterized by highly economic changes. Multinational work trades are working in Kuwait construction industry. There are technical personnel coming from many countries all over the world. Many of international consulting and contracting firms are working in many of major Kuwaiti projects (Mahdi and Soliman, 2019)

The usual awarding and procurement system in Kuwait is the Lowest Tender Price via the Central Authority for Public Tenders (CAPT). The traditional method is using a designer for the design stage and awarding the tender to the bidder with the lowest price. The design documents should be prepared before the project start. Many public and private projects are using also Construction Management (CM) contracts, especially for big projects.

\section{DISCUSSION AND ANALYSIS}

\section{Data Gathering and Sampling}

A set of approved contractor S-curves for many projects in Kuwait is gathered for the period from 2009 to 2019. Approving contractor S-curves is a part of contractor planning and schedule process. The process of project plan approval is going through indefinite sequential steps. First, the master project schedule is approved, and then the detailed project tasks planning and schedule program are approved. To get approval on the detailed project tasks planning and schedule program, it takes many of revision cycles from all project stakeholders such as owner, engineers, and public authorities. The used project S-curve is the last approval step of contractor planning and schedule process. The approved S-curve is used as a tool for project time and cost control.

This set of approved contractor S-curves is chosen based on the availability and acceptance of stakeholder to use their project cash flow. The set of projects varies from governmental and private projects. Some of these cash flows were excluded because of mistakes of production or missing data, which cannot be used. The set of projects is divided into two groups based on owner type as governmental or private owner. Each set of projects of clients is 
then divided into three types of projects: one-building project, multibuilding projects, and one high rise building project. The group of one-building project contains the projects of one building of one or two floors. This type of projects contains small villas, mosques, bank branches, service building, and car parks. Multibuilding projects contains the project of more than one building of a small number of floors. This group contains central hospitals, sports clubs, commercial malls, and educational buildings. The high rise building contains ministries headquarters and office and residential buildings. Although these projects differ slightly in internal finishing quality, they have common features, such as the fact that they have common structural and electromechanical systems. Table 1 shows the numbers and summary of surveyed projects divided into six groups of projects.

Table 1. Number of the surveyed projects.

\begin{tabular}{|c|c|c|c|c|c|c|c|}
\hline \multirow{2}{*}{ Type of Project } & \multicolumn{2}{|c|}{$\begin{array}{c}\text { Project Owner - Number of } \\
\text { Projects }\end{array}$} & \multirow{2}{*}{ Total } & \multicolumn{2}{|c|}{ Duration Range } & \multicolumn{2}{|c|}{ Budget Range } \\
\hline & Governmental & Private & & $\begin{array}{l}\text { Min } \\
\text { (Days) }\end{array}$ & $\begin{array}{l}\text { Max } \\
\text { (Days) }\end{array}$ & $\begin{array}{l}\mathrm{KD}^{*} \\
\text { (Min) }\end{array}$ & $\begin{array}{l}\text { KD* } \\
\text { (Max.) }\end{array}$ \\
\hline One-building project & 8 & 7 & 15 & 279 & 730 & 334,793 & $5,400,000$ \\
\hline $\begin{array}{l}\text { Multibuilding } \\
\text { projects }\end{array}$ & 9 & 5 & 14 & 239 & 1642 & 337,000 & $220,689,359$ \\
\hline $\begin{array}{l}\text { Multifloor buildings } \\
\text { - high rise }\end{array}$ & 6 & 13 & 19 & 419 & 1337 & 850,000 & $76,794,999$ \\
\hline Total & & 48 & & & & & \\
\hline
\end{tabular}

$* \mathrm{KD}=3.33 \mathrm{US} \$$

\section{S-Curves for Different Types of Construction Projects}

Figures 1 and 2 show the behavior for S-curves for different types of construction projects. Figure 1 shows the S-curves for private owning projects. For one-building projects, it is noticed that the attitude of the projects $\mathrm{S}$ curve is almost straight and almost identical for all projects up to $10 \%$ of the project life. The percentage of cumulative cost is almost $4 \%$ at $10 \%$ of project duration. In this early project stage, there are only some arrangement tasks that are executed. The tasks that are executed in this stage are activities related to earthwork and concrete substructure. These activities in general consume less expenses compared to the rest of the project activities. The attitude of curves then starts to be different. This is because of starting other activities such as superstructure, finishing, and electromechanical activities. These activities and their costs vary based on owner desires. On average, $25 \%$ of incurred costs are with $50 \%$ of project time.

Regarding private owning multibuilding projects, it is shown that, from project start, the attitude of S-curve is different for all projects. This behavior has resulted from the change of characteristics for each project and different numbers of buildings per each project.

Regarding the S-curves private owning high rise buildings, it is shown that most of the surveyed projects in the first $10 \%$ of the project are very similar. The gap between curves differs after the starting stage. The average Scurves for this type of projects are almost smooth. Figure 2 shows the S-curves for governmental owning different types of projects. Regarding one building for governmental projects, the behavior of S-curve is almost identical up 
to $15 \%$ of project life, then starting to widening after that. The attitude of all surveyed projects is almost similar with almost parallel curves. As noticed, the average curve indicates that about $85 \%$ of project time consumes almost $70 \%$ of estimate project cash out. It indicates that the rest of $15 \%$ of project time needs $30 \%$ of project estimate cost. This is due to the fact that the electromechanical systems and cladding work in this stage. These activities consume a high percentage of project estimate cost.
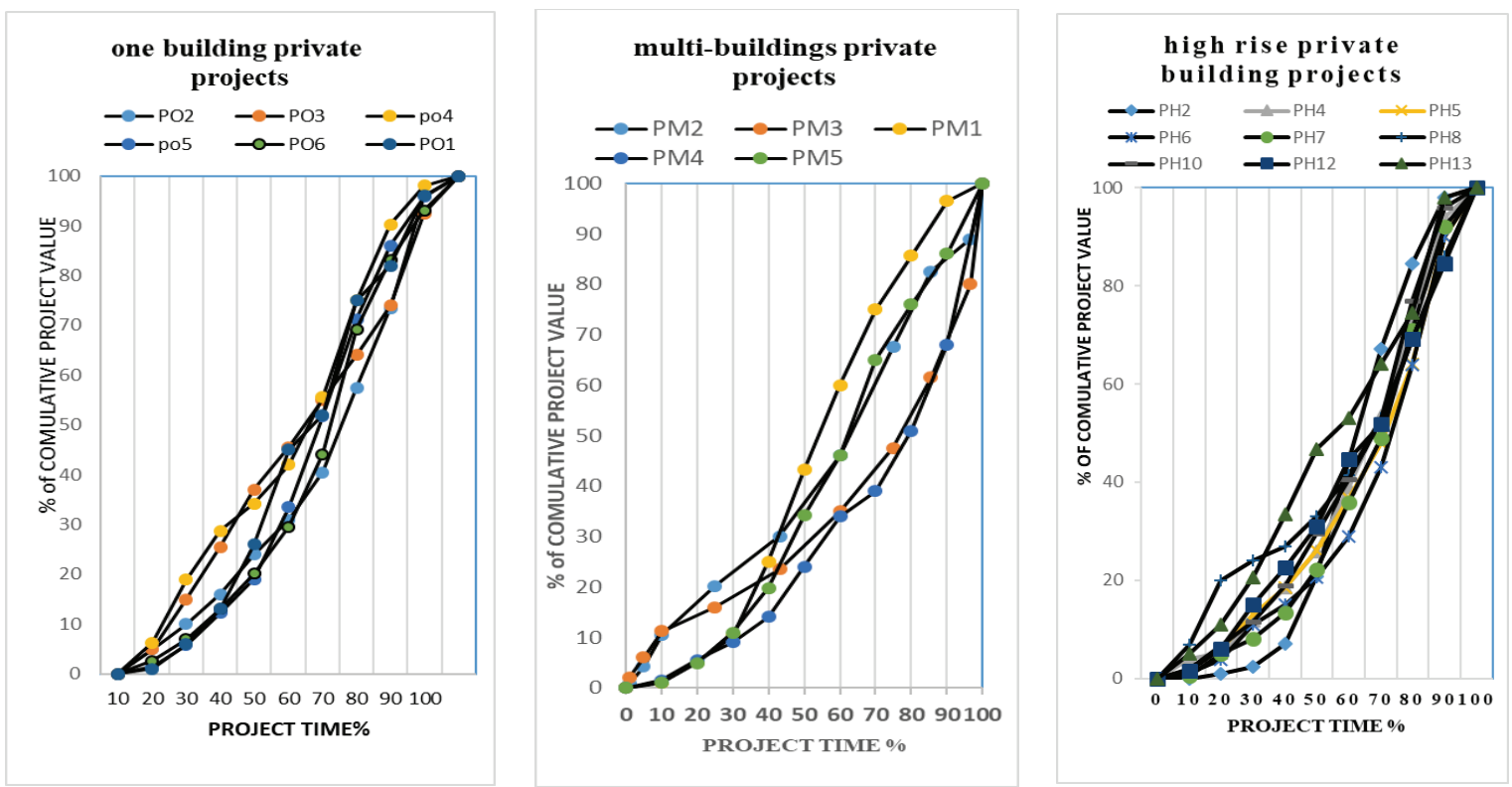

Figure 1. S-curves for Private Projects for Different Types of Project.
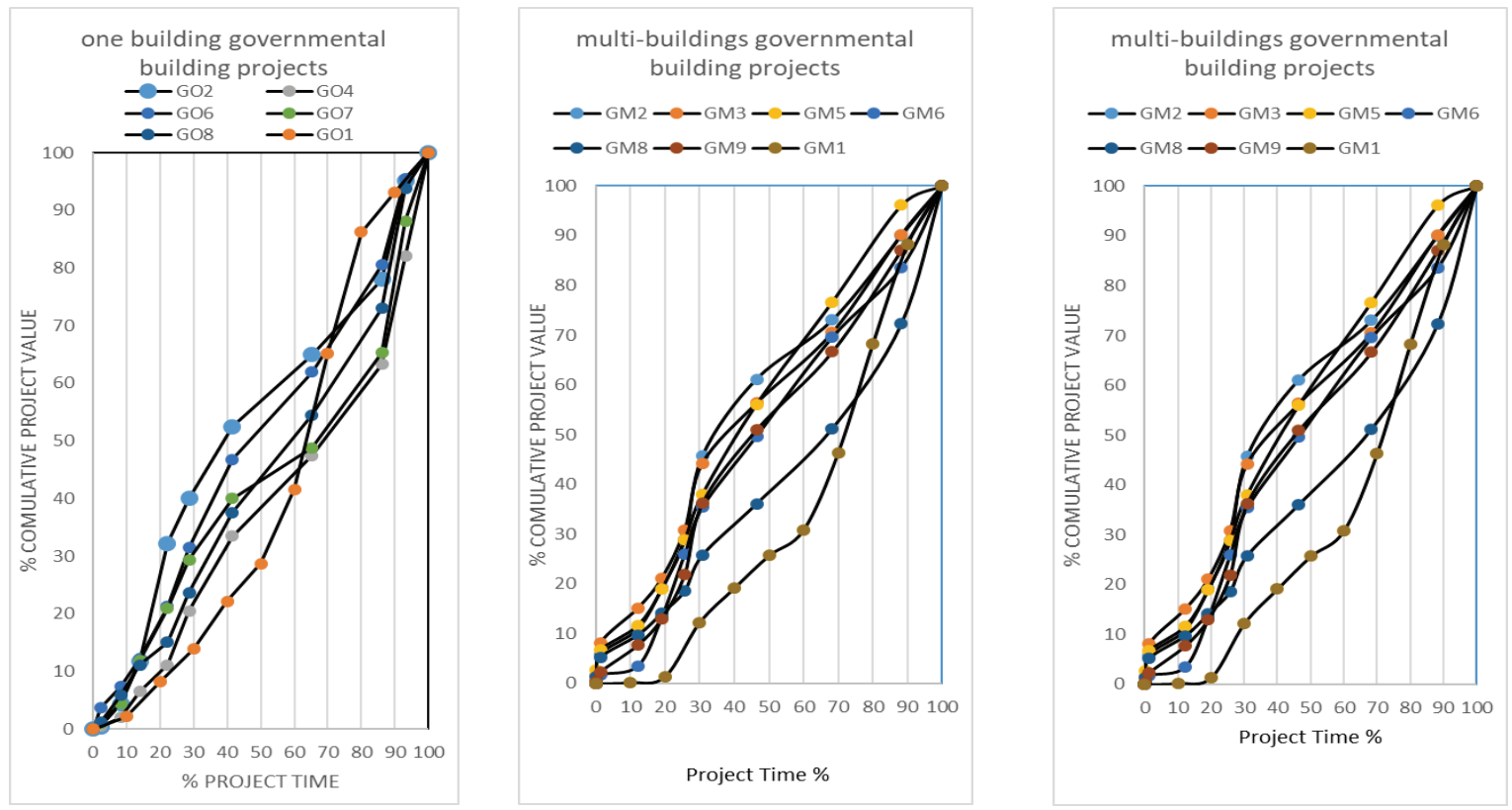

Figure 2. S-curves for Governmental Projects for Different Types of Project. 
Regarding the S-curves for governmental multibuilding project, it is shown that there is no similarity for curve attitude for this type of project. There is a big difference for the curves from project start. This difference of project attitude resulted from changes of project components and changing of project number of buildings. This type of project gives more freedom to the contractor to maintain their cash flow policy. Regarding the S-curves for high rise building of governmental projects, there is a similarity of curves attitude through project life for the surveyed project of this type of project.

\section{S-Curves Gaping Analysis for Different Types of Construction Projects}

In this section, a gap analysis for the S-curves attitude for each one of the surveyed six groups is explained. The gap difference for each type of surveyed project is calculated as the gap between the maximum and minimum values of each type of project for the different surveyed projects groups. Gap value is calculated at a certain time by subtracting the minimum percentage of cost estimate from the maximum percentage at the same time period. The chosen time period is for every $10 \%$ of project duration. Figure 3 describes the difference for values for S-curves for different types of construction projects. As shown in Figure 8, the maximum difference between the upper and lower curves for one building for private owning projects is about $26.3 \%$, which existed in the middle stage of project $(40-50 \%)$ of project life. For the projects of private owning for multibuilding projects, the maximum difference for the mentioned S-curve is about $36 \%$ in $70-80 \%$ of the project duration. The project of high rise private owning projects has the maximum difference in S-curve values, which is about 24 to $26 \%$ for the middle part of the project life from $40-70 \%$ of the project lifetime. For the governmental one-building projects, the maximum difference is laying in two parts: one in the middle part of the project of value of $21.1 \%$ in $40 \%$ of the project life. The other part is in the last third of the project, about $22.9 \%$ on the $80 \%$ of project life. For multibuilding project of governmental projects, there is a big gap between surveyed projects in the last third of the project, about $25 \%$ difference in $70-80 \%$ of the project life. The high rise governmental projects have a gradual difference of surveyed S-curves up to $60 \%$ of the project life. The maximum difference in this type of projects is $17.9 \%$ on $60 \%$ of project lifetime. There is a maximum gap between S-curves for different types of project. This gap varies between $17 \%$ and $36 \%$, and the maximum gap lies between $40 \%$ and $80 \%$ of the project life. These differences are due to the change in the project types.

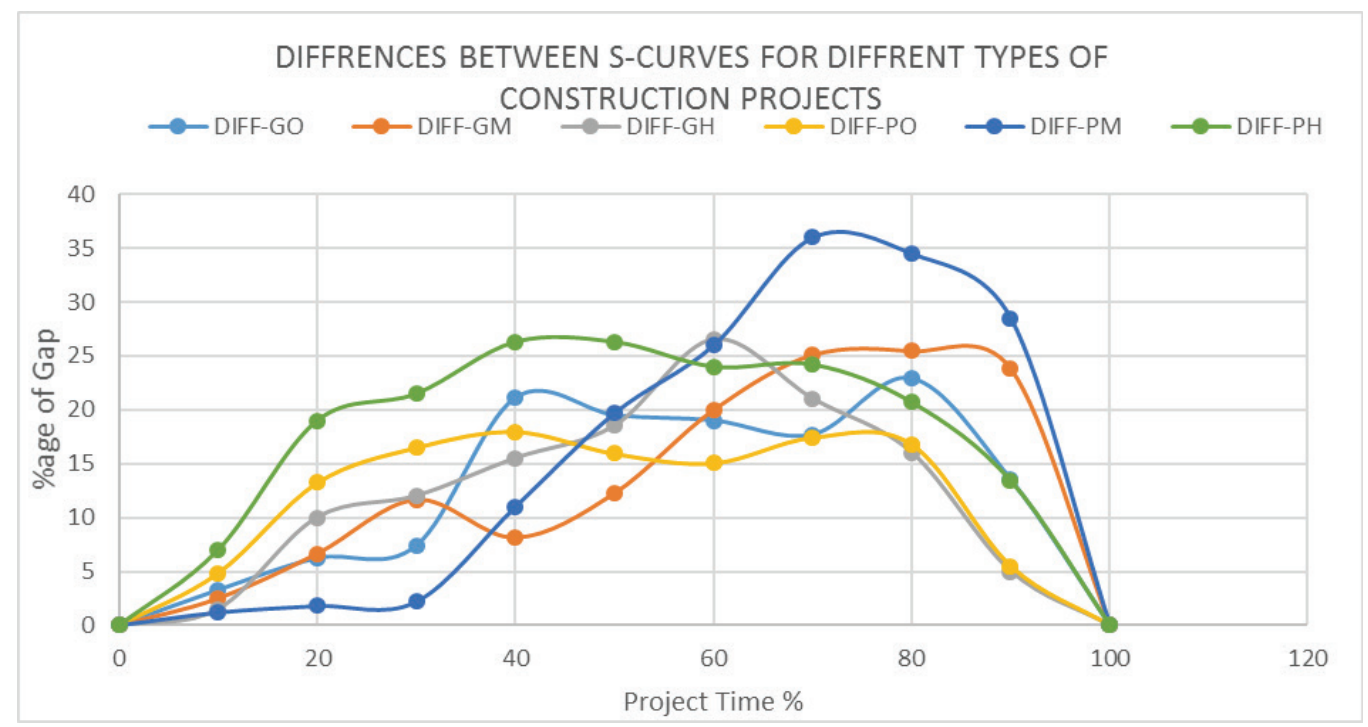

Figure 3. Gap differences of S-curves for different types of construction projects. 


\section{Comparing Curves for Averages for the Project Types Groups}

To investigate the differences or similarities between cash flow for the surveyed different types of projects, the averages of each type will be used. The average represents the behavior of the set of projects for each type of projects.

Figure 4 shows the averages for S-curves for the different types of construction projects. As shown in Figure 4, the lower average is for governmental multibuilding projects, while the upper average is for the private owning one-building projects. For the first third of the project lifetime, the behavior of the averages is almost the same for private and governmental multi- and high rise building projects. For the second third and up to $80 \%$ of project life, the attitudes of the average S-curves for the governmental one, high rise building, and private multi- and high rise building projects are almost identical. The variance of S-curve behavior indicates that there is no common attitude for all types of construction project types.

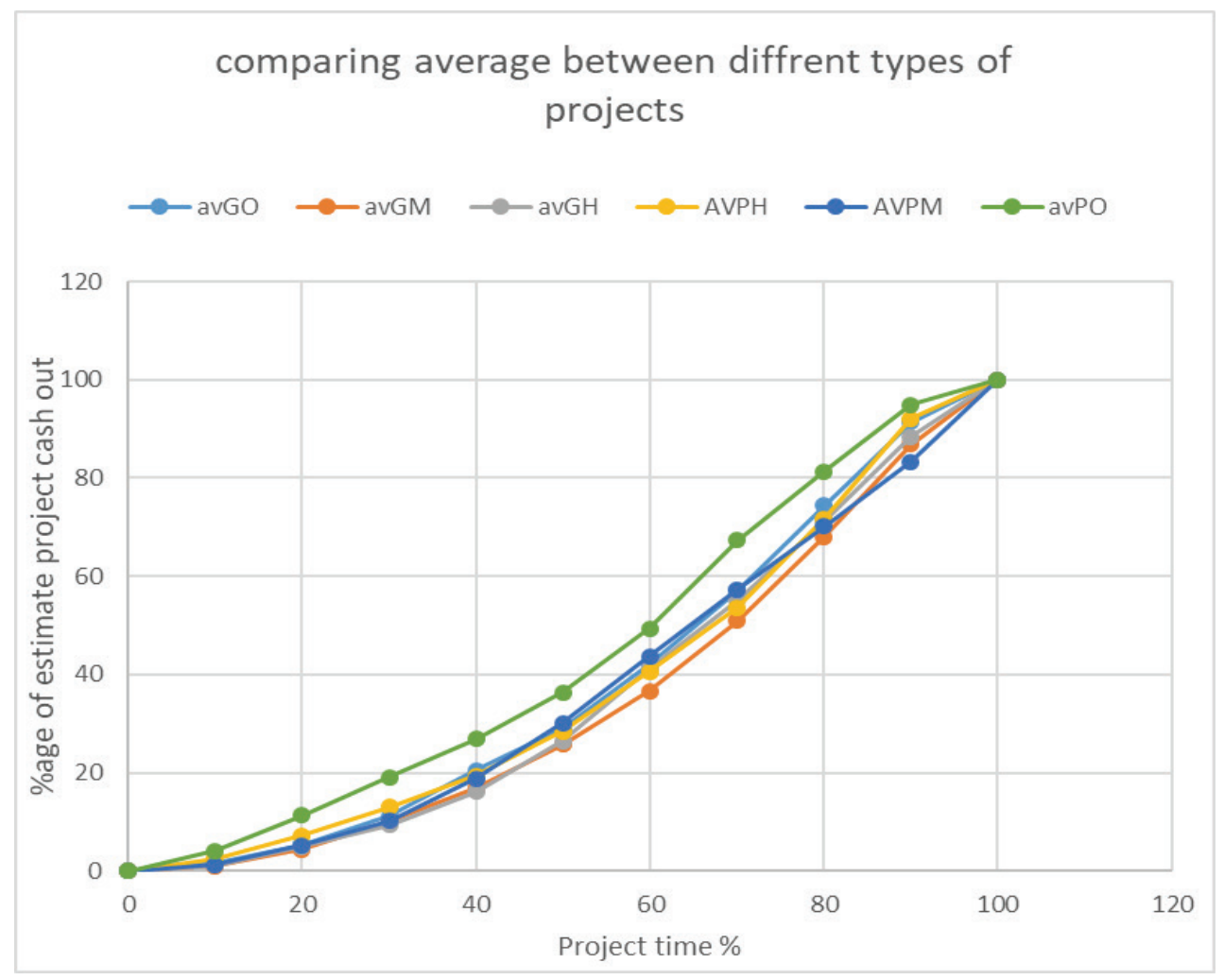

Figure 4. Comparing between cash flow averages of the project types.

\section{Statistical Analysis for Averages of Different Types of Construction Projects}

To test the similarity or differences for the different types of surveyed construction projects, a statistical analysis is applied. Average values for the different types of construction projects are statistically analyzed to investigate the level of similarity or difference. Two statistical analyses are implied: T-paired test and the Standard Euclidean distance. T-paired test is applied for comparing means values between surveyed project types groups, and Standard Euclidean distance is applied for measuring the similarity between S-curves values for the different types of surveyed projects. 
The T-paired test is applied only for normal distributed samples; so before applying T-paired test, a test of normality should be applied.

\section{Test of Normality}

As shown in Table 2, all Kolmogorov-Smirnov significant values are more than 0.05 , which indicates that the samples are in normal distribution, and the sample can be compared by T-paired test.

Table 2. Test of Normality Significance values - SPSS 26.

\begin{tabular}{|c|c|c|c|c|c|c|c|}
\hline & \multirow{2}{*}{ PRGGROPS } & \multicolumn{3}{|c|}{ Kolmogorov-Smirnov } & \multicolumn{3}{|c|}{ Shapiro-Wilk } \\
\hline & & Statistic & $\mathrm{df}$ & Sig. & Statistic & $\mathrm{df}$ & Sig. \\
\hline \multirow{6}{*}{ SCURVES } & PO & .157 & 11 & $.200^{*}$ & .899 & 11 & .182 \\
\hline & PM & .164 & 11 & $.200^{*}$ & .894 & 11 & .156 \\
\hline & $\mathrm{PH}$ & .178 & 11 & $.200^{*}$ & .893 & 11 & .150 \\
\hline & GO & .162 & 11 & $.200^{*}$ & .900 & 11 & .184 \\
\hline & GM & .164 & 11 & $.200^{*}$ & .912 & 11 & .257 \\
\hline & GH & .141 & 11 & $.200^{*}$ & .919 & 11 & .313 \\
\hline
\end{tabular}

$P O=$ private one-building projects, $P M=$ private multi-building projects, $P H=$ private high rise building projects, $G O=$ governmental one-building projects, $G M=$ governmental multi-building projects $G H=$ governmental high rise building projects.

\section{T-Paired Test}

To evaluate the impact of similarity between two patterns of S-curves for the different types of surveyed project, T-paired test is applied. The T-paired test is used to compare the means between two different groups of normal distribution samples. Student's t-Test is used to ascertain if the null hypothesis can be accepted or rejected. The null hypothesis is accepted if the two means for the two different groups are the same. Alternative hypothesis: if the two means are not the same. From the paired two-samples results, if the significance level is bigger than 0.05 , then reject the null hypothesis and accept alternative hypothesis, and if the significance level is less than 0.05 , then accept the null hypothesis.

Table 3 shows the paired samples statics between each two different types of surveyed groups. Most of the Tpaired sample tests are significantly less than $5 \%$, which indicates that the hypothesis of same mean values is rejected, and there is a statistical significant difference between surveyed project types means. 


\section{Standard Euclidean Distance}

Standard Euclidean distance is a value that can be used to measure the near or widening of two different curves. The smallest the standard Euclidean distance, the more similar the two curves. The Euclidean distance is calculated based on the absolute difference value between two points at the same percentage of project lifetime. As shown in Table 4, the closest curves are between governmental high rise building and governmental one building, while the biggest gap is between government multibuilding projects and one-building private owning projects Scurves. As shown in Table 4, the S-curves for all types of construction projects for governmental projects are nearly close.

Table 3. T-paired sample test values.

\begin{tabular}{|c|c|c|c|c|c|c|c|c|}
\hline \multicolumn{9}{|c|}{ Paired Samples Test } \\
\hline & \multicolumn{5}{|c|}{ Paired Differences } & \multirow{3}{*}{$\mathrm{t}$} & \multirow{3}{*}{$\mathrm{df}$} & \multirow{3}{*}{$\begin{array}{l}\text { Sig. } \\
\text { (2- } \\
\text { tailed) }\end{array}$} \\
\hline & \multirow{2}{*}{ Mean } & \multirow{2}{*}{$\begin{array}{c}\text { Std. } \\
\text { Deviation }\end{array}$} & \multirow{2}{*}{$\begin{array}{l}\text { Std. Error } \\
\text { Mean }\end{array}$} & \multicolumn{2}{|c|}{$\begin{array}{l}\text { 95\% Confidence Interval } \\
\text { of the Difference }\end{array}$} & & & \\
\hline & & & & Lower & Upper & & & \\
\hline GO - GM & 2.9052381 & 2.4822016 & .7484119 & 1.2376724 & 4.5728038 & 3.882 & 10 & .003 \\
\hline $\mathrm{GO}-\mathrm{GH}$ & 1.6712121 & 1.4573435 & .4394056 & .6921554 & 2.6502688 & 3.803 & 10 & .003 \\
\hline $\mathrm{GO}-\mathrm{PH}$ & .3536364 & 1.7431321 & .5255741 & -.8174157 & 1.5246884 & .673 & 10 & .516 \\
\hline GO - PM & 1.1112121 & 2.7576920 & .8314754 & -.7414306 & 2.9638548 & 1.336 & 10 & .211 \\
\hline $\mathrm{GO}-\mathrm{PO}$ & -5.2933333 & 3.3235345 & 1.0020834 & -7.5261142 & -3.0605525 & -5.282 & 10 & .000 \\
\hline GM - GH & -1.2340260 & 1.9570732 & .5900798 & -2.5488056 & .0807537 & -2.091 & 10 & .063 \\
\hline GM - PH & -2.5516017 & 1.5763198 & .4752783 & -3.6105878 & -1.4926157 & -5.369 & 10 & .000 \\
\hline GM - PM & -1.7940260 & 3.0870858 & .9307914 & -3.8679585 & .2799065 & -1.927 & 10 & .083 \\
\hline GM - PO & -8.1985714 & 5.3537403 & 1.6142134 & -11.7952631 & -4.6018797 & -5.079 & 10 & .000 \\
\hline $\mathrm{GH}-\mathrm{PH}$ & -1.3175758 & 1.8280275 & .5511710 & -2.5456613 & -.0894902 & -2.391 & 10 & .038 \\
\hline GH - PM & -.5600000 & 2.3571964 & .7107215 & -2.1435861 & 1.0235861 & -.788 & 10 & .449 \\
\hline $\mathrm{GH}-\mathrm{PO}$ & -6.9645455 & 4.2831572 & 1.2914205 & -9.8420096 & -4.0870813 & -5.393 & 10 & .000 \\
\hline PH - PM & .7575758 & 3.3576999 & 1.0123846 & -1.4981577 & 3.0133092 & .748 & 10 & .472 \\
\hline $\mathrm{PH}$ - PO & -5.6469697 & 4.3892514 & 1.3234091 & -8.5957089 & -2.6982305 & -4.267 & 10 & .002 \\
\hline PM - PO & -6.4045455 & 4.1056330 & 1.2378949 & -9.1627472 & -3.6463437 & -5.174 & 10 & .000 \\
\hline
\end{tabular}


The Standard Euclidean distances are 7.2084, 7.4194, and 12.4281 for one- and high rise buildings projects, multibuilding, and high rise building projects, and between one- and multibuilding projects, respectively. For private owning, these values are $23.3115,10.9112$, and 24.8950 , indicating that the behavior of S-curves in private owning project is more independent than that for governmental projects. Then, compare Standard Euclidean distance for each type of project. For high rise building, the distance value between the private and governmental building is 7.2466, which indicates that there is high similarity for the S-curves for this type of projects with no interfering of owner type. For multibuilding projects, the value is 11.4326; this indicates that there is moderate similarity with this type of projects. Regarding the one-building project, the value of standard Euclidean distance is 20.4615. This value indicates that the similarity of S-curve for this type of project is low. This result is ascertained by calculating the correlation coefficient between the groups of projects surveyed. Table 5 shows the correlation coefficient for the surveyed groups. The maximum correlation factor is 0.999 , significantly correlating between groups of GM, PH, GH, GM, and GO, while the least correlation is between Po and GM.

Table 4. Standard Euclidean distance for different types of projects' S-curves.

\begin{tabular}{|c|c|c|c|c|c|c|}
\hline & GO & GM & GH & PO & PM & PH \\
\hline GO & 0.0000 & 12.4281 & 7.2084 & 20.4615 & 9.4674 & $\mathbf{5 . 6 3 5 7}$ \\
\hline GM & & 0.0000 & 7.4197 & $\mathbf{3 2 . 0 3 1 4}$ & 11.4326 & 9.8217 \\
\hline GH & & & 0.0000 & 26.7770 & 7.6820 & 7.2466 \\
\hline PO & & & & 0.0000 & 24.8950 & 23.3115 \\
\hline PM & & & & & 0.0000 & 10.9112 \\
\hline PH & & & & & & 0.0000 \\
\hline
\end{tabular}

Table 5. Correlation coefficient for different types of projects' S-curves.

\begin{tabular}{|c|c|c|c|c|c|c|c|}
\hline \multicolumn{8}{|c|}{ Correlations } \\
\hline & & $\mathrm{GO}$ & GM & $\mathrm{GH}$ & $\mathrm{PH}$ & $\mathrm{PM}$ & $\mathrm{PO}$ \\
\hline \multirow{3}{*}{ GO } & Pearson Correlation & 1 & $.998^{* *}$ & $.999^{* *}$ & $.999^{* *}$ & $.998^{* *}$ & $.996^{* *}$ \\
\hline & Sig. (2-tailed) & & .000 & .000 & .000 & .000 & .000 \\
\hline & $\mathrm{N}$ & 11 & 11 & 11 & 11 & 11 & 11 \\
\hline \multirow{3}{*}{ GM } & Pearson Correlation & $.998^{* *}$ & 1 & $.999^{* *}$ & $.999^{* *}$ & $.996^{* *}$ & $.989^{* *}$ \\
\hline & Sig. (2-tailed) & .000 & & .000 & .000 & .000 & .000 \\
\hline & $\mathrm{N}$ & 11 & 11 & 11 & 11 & 11 & 11 \\
\hline \multirow{3}{*}{ GH } & Pearson Correlation & $.999^{* *}$ & $.999^{* *}$ & 1 & $.999^{* *}$ & $.998^{* *}$ & $.993^{* *}$ \\
\hline & Sig. (2-tailed) & .000 & .000 & & .000 & .000 & .000 \\
\hline & $\mathrm{N}$ & 11 & 11 & 11 & 11 & 11 & 11 \\
\hline \multirow{3}{*}{$\mathrm{PH}$} & Pearson Correlation & $.999^{* *}$ & $.999^{* *}$ & $.999^{* *}$ & 1 & $.996^{* *}$ & $.993^{* *}$ \\
\hline & Sig. (2-tailed) & .000 & .000 & .000 & & .000 & .000 \\
\hline & $\mathrm{N}$ & 11 & 11 & 11 & 11 & 11 & 11 \\
\hline \multirow{3}{*}{ PM } & Pearson Correlation & $.998^{* *}$ & $.996^{* *}$ & $.998^{* *}$ & $.996^{* *}$ & 1 & $.994^{* *}$ \\
\hline & Sig. (2-tailed) & .000 & .000 & .000 & .000 & & .000 \\
\hline & $\mathrm{N}$ & 11 & 11 & 11 & 11 & 11 & 11 \\
\hline \multirow{3}{*}{$\mathrm{PO}$} & Pearson Correlation & $.996^{* *}$ & $.989^{* *}$ & $.993^{* *}$ & $.993^{* *}$ & $.994^{* *}$ & 1 \\
\hline & Sig. (2-tailed) & .000 & .000 & .000 & .000 & .000 & \\
\hline & $\mathrm{N}$ & 11 & 11 & 11 & 11 & 11 & 11 \\
\hline
\end{tabular}

** Correlation is significant at the 0.01 level (2-tailed). 


\section{LIMITATION AND FUTURE RESEARCH WORK}

This study results are limited to the similar construction industries such as Kuwait construction industry. The future works will study the modelling of the behavior of contractors' cash flow for different types of construction projects in mathematical modelling.

\section{CONCLUSION}

This study aimed to analyze the differences and similarities of contractor S-curves for different types of construction projects. The number of contractor S-curves was collected from the state of Kuwait. This list of projects is divided into six groups of project types. Statistical analysis tools are used to test the similarities and changes between these group of projects using test of normality, T-paired test, and standard Euclidean distance. The S-curves for the projects of high rise building and one-building projects groups have a certain degree of similarity, while the S-curves for multibuilding projects are different from project start. The maximum gap between the surveyed S-curves is laying in the middle part of project duration in high rise building, while it is located in $75 \%$ of project duration for multibuilding projects. For project groups average S-curves, the lower average is for governmental multibuilding projects, while the upper average is for the private owning one-building projects. Standard Euclidean Distance is used to measure the similarity of groups S-curves. Standard Euclidean Distance showed that closest curves are between private high rise building and governmental one building, while the biggest gap is between government multibuilding projects and one-building private owning projects S-curves. The S-curves for governmental projects for different types have a degree of similarity, while this is not true for private projects. The S-curves for high rise building for both types of clients are similar. The research results can be used to indicate that the S-curves have different behaviors based on changing of project type and project clients.

\section{REFERENCES}

Banki, M. T., and Esmaeili, B. 2009. The effects of variability of the mathematical equations and project categorizations on forecasting S-curves at construction industry. International Journal of Civil Engineering 7(4): 258-270.

Barraza, G.A., Back, W.E., Mata, F. 2000. Probabilistic monitoring of project performance using S-curves. Journal of Construction Engineering Management ASCE. 126 (2): 142-8

Cheng, Y.M., Yu, C.H., Wang, H.T. 2011. Short-Interval dynamic forecasting for actual S-curve in the construction phase. Journal of Construction Engineering and Management ASCE. 137 (11) :933-41.

Cristóbal, J R S 2017. The S-curve envelope as a tool for monitoring and control of projects. Procedia Computer Science 121: 756-761.

Dhamodaran,G. and Divakar, K.R. 2019. Estimation of cash flow from value of work done for construction projects in India. International Journal of Engineering and Advanced Technology (IJEAT) ISSN: 2S2 (8) : 433-437

Dubem I. Ikediashi, D. I. \& Kevin C. Okolie, K. C. 2020. An assessment of risks associated with contractor's cash flow projections in South-Nigeria. International Journal of Construction Management, DOI: $10.1080 / 15623599.2020 .1764752$

Halpin, D. W., \& Senior, B. 2009. Financial management and accounting fundamentals for construction. Hoboken, NJ: John Wiley \& Sons

Hwee, N. G. and Tiong, R. L. 2002. Model on cash flow forecasting and risk analysis for contracting firms. International Journal of Project Management, 20 (5): 351-363 
Kaka, A.P. 1999. The development of a benchmark model that uses historical data for monitoring the progress of current construction projects. Engineering, Construction and Architectural Management. 6 (3):256-66.

Kenley, R. 2003. Financing construction. London, England: Spon Press.

Kuwait CSB - Central Statistical Bureau 2019. https://www.csb.gov.kw/Pages/Statistics_en?ID=69\&ParentCatID=\%203

Mahdi, I. \& Soliman, E. 2018. Significant and top-ranked delay factors in Arabic Gulf countries, International Journal of Construction Management, DOI: 10.1080/15623599.2018.1512029

Mavrotas, G., Caloghirou, Y., Koune, J. 2005. A model on cash flow forecasting and early warning for multiproject programmes: application to the operational program for the information society in Greece. International Journal of Project Management. 23 (2):121-3

Murmis, GM. 1997. S curves for monitoring project progress. Project Manage J 1997: 29-35.

Navon, R. 1996. Company-Level cash-flow management. Journal of Construction Engineering and Management. 122 (1): 22- 29

Shash, A. A. \&Qarra, A. A. 2018. Cash Flow Management of Construction Projects in Saudi Arabia. Project Management Journal. 49(5): 48-63;

Tarek, Z., \& Yaqiong, L. 2014. Cash flow modelling for construction projects. Engineering, Construction and Architectural Management. 21(2): 170-189. 